Prepared in cooperation with

Department of Navy,

Naval Facilities Engineering Command,

Engineering Field Activity, Northwest

\title{
Evidence for Chloroethene Biodegradation in Ground Water at the Former Building 957 Drum Storage Area, Area 2, Operable Unit 2, Naval Undersea Warfare Center, Division Keyport, Washington
}

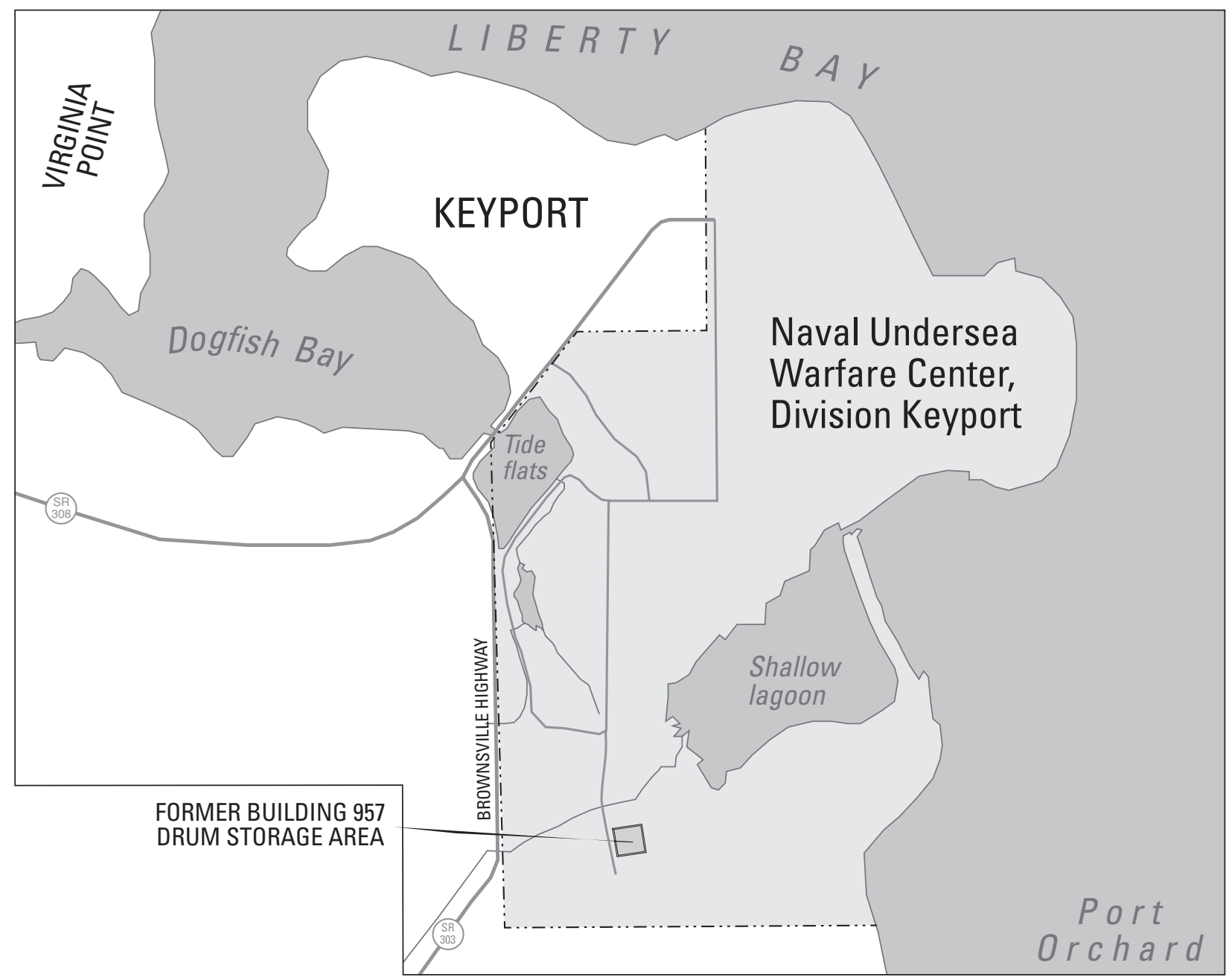

Scientific Investigations Report 2006-5030

U.S. Department of the Interior

U.S. Geological Survey 


\section{Evidence for Chloroethene Biodegradation in Ground Water at Former Building 957 Drum Storage Area, Area 2, Operable Unit 2, Naval Undersea Warfare Center, Division Keyport, Washington}

By R.S. Dinicola

Prepared in cooperation with

Department of Navy

Naval Facilities Engineering Command

Engineering Field Activity, Northwest

Scientific Investigations Report 2006-5030 


\title{
U.S. Department of the Interior \\ Gale A. Norton, Secretary \\ U.S. Geological Survey \\ P. Patrick Leahy, Acting Director
}

\section{U.S. Geological Survey, Reston, Virginia: 2006}

\author{
For sale by U.S. Geological Survey, Information Services \\ Box 25286, Denver Federal Center \\ Denver, CO 80225 \\ For more information about the USGS and its products: \\ Telephone: 1-888-ASK-USGS \\ World Wide Web: http://www.usgs.gov/
}

\footnotetext{
Any use of trade, product, or firm names in this publication is for descriptive purposes only and does not imply endorsement by the U.S. Government.

Although this report is in the public domain, permission must be secured from the individual copyright owners to reproduce any copyrighted materials contained within this report.

Suggested citation:

Dinicola, R.S., 2006, Evidence for chloroethene biodegradation in ground water at former Building 957 drum storage area, Area 2, Operable Unit 2, Naval Undersea Warfare Center, Division Keyport, Washington: U.S. Geological Survey Scientific Investigations Report 2006-5030, 12 p.
} 


\section{Contents}

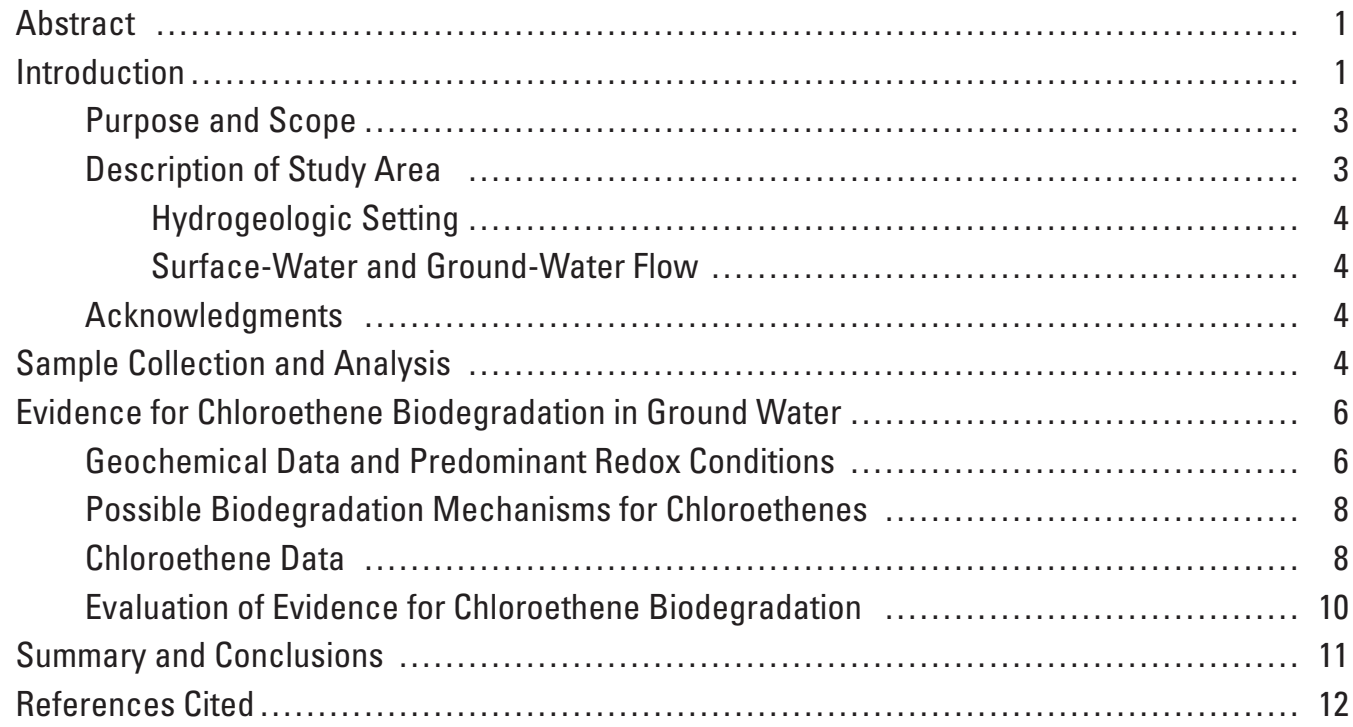

\section{Figures}

Figure 1. Map showing location of former Building 957 drum storage area, Area 2, Naval Undersea Warfare Center, Division Keyport, Washington

Figure 2. Map showing location of monitoring wells and June 2003 water level altitudes at former Building 957 drum storage area, Area 2, Naval Undersea Warfare Center, Division Keyport, Washington ....

Figure 3. Map showing concentrations of trichloroethene (TCE), cis-dichloroethene (cis-DCE), and vinyl chloride (VC) in ground water at former Building 957 drum storage area, Area 2, Naval Undersea Warfare Center, Division Keyport, Washington, June and August 2003

\section{Tables}

Table 1. Construction data and water-level measurements for selected monitoring wells at former Building 957 drum storage area, Area 2, Naval Undersea Warfare Center, Division Keyport, Washington, June 23, 2003

Table 2. Predominant reduction-oxidation (redox) conditions and ground-water geochemical data collected at former Building 957 drum storage area, Area 2, Naval Undersea Warfare Center, Division Keyport, Washington, June 23, 2003

Table 3. Potential relative efficiency of chloroethene biodegradation through microbial reductive dechlorination or microbial oxidation as a function of in situ redox conditions

Table 4. Chloroethene concentrations in ground water at former Building 957 drum storage area, Area 2, Naval Undersea Warfare Center, Division Keyport, Washington, 1991 to 2004 


\section{Conversion Factors, Datums, and Acronyms and Abbreviations}

CONVERSION FACTORS

\begin{tabular}{lcl}
\hline \multicolumn{1}{c}{ Multiply } & By & \multicolumn{1}{c}{ To obtain } \\
\hline acre & 4,047 & square meter \\
acre & 0.4047 & hectare \\
foot (ft) & 0.3048 & meter \\
feet per foot (ft/ft) & 0.3048 & meter per meter \\
foot per day (ft/d) & 0.3048 & meter per day \\
gallon (gal) & 3.785 & liter \\
inch (in.) & 2.54 & centimeter \\
\hline
\end{tabular}

Temperature in degrees Fahrenheit $\left({ }^{\circ} \mathrm{F}\right)$ may be converted to degrees Celsius $\left({ }^{\circ} \mathrm{C}\right)$ as follows:

$$
{ }^{\circ} \mathrm{C}=\left({ }^{\circ} \mathrm{F}-32\right) / 1.8 \text {. }
$$

Specific conductance is given in microsiemens per centimeter at 25 degrees Celsius $\left(\mu \mathrm{S} / \mathrm{cm}\right.$ at $\left.25^{\circ} \mathrm{C}\right)$.

Concentrations of chemical constituents in water are given either in milligrams per liter (mg/L), micrograms per liter $(\mu \mathrm{g} / \mathrm{L})$, or nanomoles per liter (nanomolar). One milligram per liter is equivalent to one thousand micrograms per liter. One microgram per liter is equivalent to "parts per billion."

DATUMS

Vertical coordinate information is referenced to the North American Vertical Datum of 1988 (NAVD 1988).

Horizontal coordinate information is referenced to the North American Datum of 1927 (NAD 27).

Altitude, as used in this report, refers to distance above the vertical datum.

ACRONYMS AND ABBREVIATIONS

\begin{tabular}{ll}
\hline \multicolumn{1}{c}{ Acronym and abbreviation } & \multicolumn{1}{c}{ Meaning } \\
\hline NWQL & National Water Quality Laboratory \\
USGS & U.S. Geological Survey \\
1,2-DCE & total 1,2-dichloroethene \\
cis-DCE & cis-1,2-dichloroethene \\
trans-DCE & trans-1,2-dichloroethene \\
DO & dissolved oxygen \\
$\mathrm{H}_{2}$ & dissolved hydrogen \\
$\mathrm{nM}$ & nanomolar \\
$\mathrm{PCE}$ & Tetrachloroethene \\
$\mathrm{TCE}$ & Trichloroethene \\
$\mathrm{VC}$ & vinyl chloride \\
VOC & volatile organic compound \\
$\mu \mathrm{m}$ & micrometer \\
\hline
\end{tabular}




\title{
Evidence for Chloroethene Biodegradation in Ground Water at Former Building 957 Drum Storage Area, Area 2, Operable Unit 2, Naval Undersea Warfare Center, Division Keyport, Washington
}

\author{
By R.S. Dinicola
}

\section{Abstract}

Shallow ground water is contaminated with the chloroethenes - trichloroethene (TCE), cis-1,2-dichloroethene (cis-DCE), and vinyl chloride (VC) - beneath the former Building 957 drum storage area at the Naval Undersea Warfare Center, Division Keyport, Washington. Chloroethene concentrations, monitored by the U.S. Navy since 1991, generally have decreased. To better understand the decrease in concentrations, the U.S. Geological Survey collected, analyzed, and evaluated water level, geochemical, and chloroethene data from eight monitoring wells at the site during June and August 2003 for evidence of chloroethene biodegradation.

The geochemical and chloroethene data clearly indicated that much of the TCE and VC, and some cis-DCE was biodegraded in ground water as it flowed beneath and slightly beyond the former Building 957 drum storage area. No apparent TCE biodegradation through any mechanism was indicated at the upgradient margin of the former drum storage area where aerobic ground water was indicated. Substantial reductive dechlorination of TCE and cis-DCE was indicated in the downgradient anaerobic ground water. Reductive dechlorination was definitively indicated by the presence of daughter products cis-DCE and VC in the downgradient wells. Ground-water redox conditions were favorable for biodegradation through microbial oxidation of VC (and cis-DCE to a lesser extent) in downgradient wells, and measured increases in the cis-DCE to $\mathrm{VC}$ ratio over time at those wells provided strong evidence for microbial oxidation of VC. All chloroethene concentrations detected in ground water at the former Building 957 drum storage area were less than $20 \mu \mathrm{g} / \mathrm{L}$. In three wells where the 2003 TCE or VC concentrations exceeded remediation goals, concentrations consistently decreased over time.

\section{Introduction}

Shallow ground water is contaminated with chloroethenes beneath the former Building 957 drum storage area at the Naval Undersea Warfare Center, Division (NUWCD) Keyport, Washington (figs. 1 and 2). Solvents, fuel, and oil were stored on the formerly unpaved area, and an estimated 4,000-8,000 gal of these chemicals were discharged to the ground (URS Consultants, Inc., 1993). Administratively, the site is part of Area 2 of Operable Unit 2 at NUWCD Keyport, and is being remediated under authority of the Comprehensive Environmental Response, Compensation, and Liability Act.

Primary contaminants of concern in ground water at Area 2 are the chloroethene compoundstrichloroethene (TCE) and vinyl chloride (VC), although cis-1,2-dichloroethene (cis-DCE) and BTEX (benzene, toluene, ethylbenzene, and xylene) also have been detected (URS Consultants, Inc., 1993). Contaminant concentrations at the site always have been relatively low, so human health risks, ecological risks, and the potential for offsite migration were determined to be low (URS Consultants, Inc., 1993). Therefore, remedies selected for Area 2 were ground-water monitoring to document the expected decrease of chloroethene concentrations, and institutional controls to exclude residential use and prevent construction of water-supply wells (URS Consultants, Inc., 1994).

Chloroethene concentrations in ground water at former Building 957 drum storage area have been monitored regularly by the U.S. Navy since 1995 to document the expected decreases in concentration due to natural attenuation processes. Data indicate that concentrations generally have decreased (CH2M HILL Constructors, Inc., 2003). To better understand the measured decreases in concentrations, the U.S. Geological Survey (USGS) collected water samples from wells at former Building 957 drum storage area, analyzed the samples for geochemical and chloroethene concentrations, and evaluated the data for evidence of chloroethene biodegradation. 


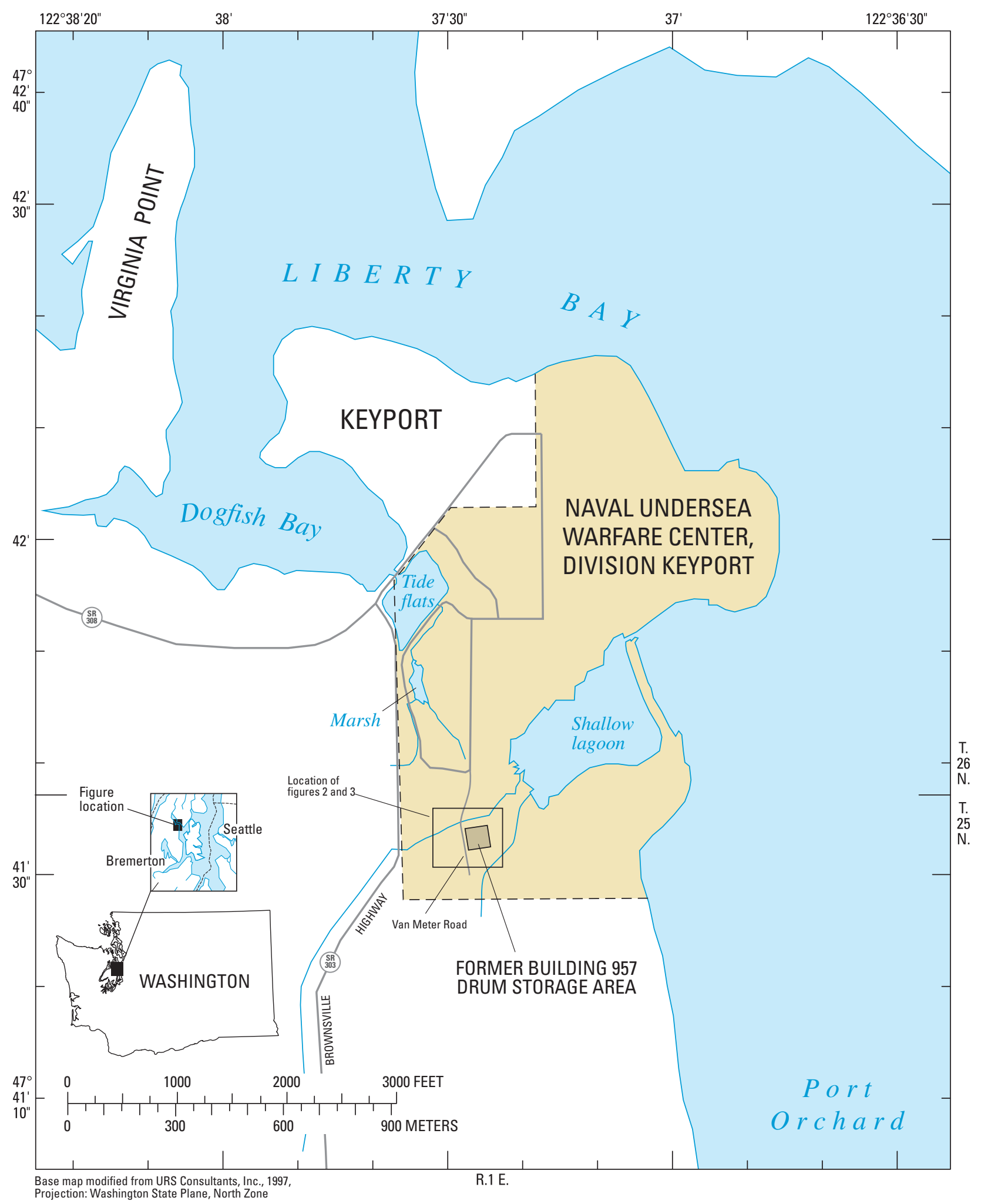

Figure 1. Location of former Building 957 drum storage area, Area 2, Naval Undersea Warfare Center, Division Keyport, Washington. 


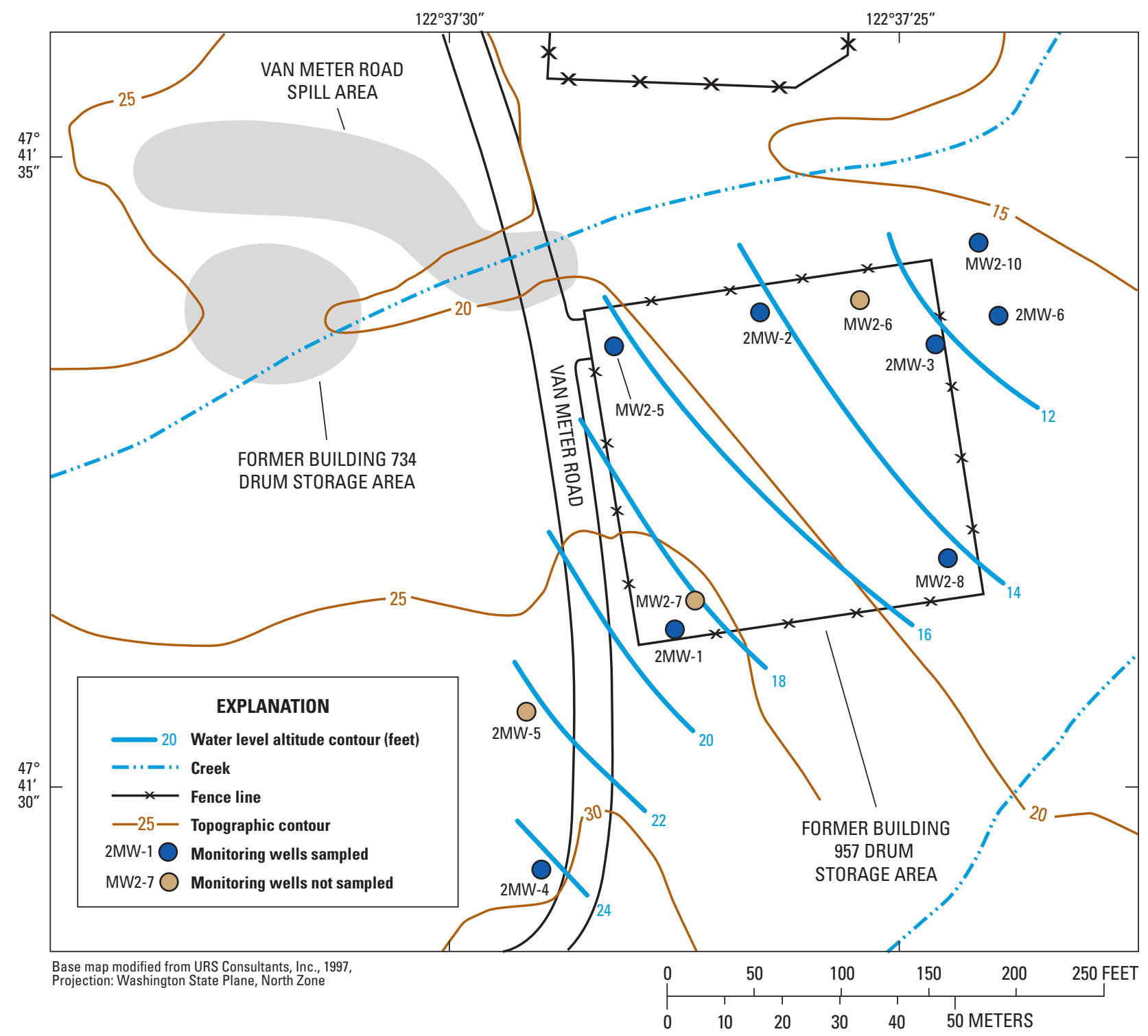

Figure 2. Location of monitoring wells and June 2003 water level altitudes at former Building 957 drum storage area, Area 2, Naval Undersea Warfare Center, Division Keyport, Washington.

\section{Purpose and Scope}

This report describes the results of a study to evaluate evidence for biodegradation of chloroethenes in ground water at former Building 957 drum storage area, Area 2, Naval Undersea Warfare Center, Division Keyport, Washington. Water level, geochemical, and chloroethene data collected by the USGS from eight wells during 2003 are presented and evaluated along with data collected by the U.S. Navy from 1991 to 2004.

\section{Description of Study Area}

NUWCD Keyport is mostly on a small peninsula in Kitsap County, Wash., in an extension of Puget Sound called Liberty Bay (fig. 1). The base occupies the eastern part of the peninsula, which is connected to the mainland by a narrow strip of land that was mostly tidal wetland before it was filled in by the Navy by the 1940s. The mainland to the west and southwest of Keyport peninsula rises steeply to rolling uplands at an altitude of 200-400 ft. 
Keyport has a temperate marine climate characterized by warm, dry summers and cool, wet winters (Washington State University, 1968). Mean annual temperature is about $51^{\circ} \mathrm{F}$; January is the coolest month and July is the warmest. Mean annual precipitation is about 31 in., 77 percent of which falls from October through March. Snowfall is infrequent and rainfall generally is not intense.

Area 2 is in the southwest corner of NUWCD Keyport (fig. 1), and includes three distinct contaminant sites: Van Meter Road spill area, former Building 734 drum storage area, and former Building 957 drum storage area (fig. 2). The onethird acre former Building 957 drum storage area is the focus of this report. The site is about $500 \mathrm{ft}$ southwest of a shallow lagoon that is an extension of Liberty Bay, and is about $40 \mathrm{ft}$ south of an unnamed creek that drains into the lagoon (fig. 1). The altitude of the site is 20 to $25 \mathrm{ft}$, and the land rises steeply to the south and west of the site. The area immediately surrounding the site is primarily forested.

\section{Hydrogeologic Setting}

NUWCD Keyport is in the Puget Sound Lowland, a topographic and structural depression between the Cascade Range to the east and the Olympic Mountains to the west. Keyport peninsula and surrounding areas are composed primarily of unconsolidated Pleistocene glacial and interglacial deposits overlying Tertiary and older bedrock (Blunt and others, 1987). A veneer of more recent alluvium, including stream, beach, landslide, and marsh deposits, covers the youngest glacial deposits in some areas. Unconsolidated deposits are more than 1,500 ft thick beneath the Keyport peninsula (Jones, 1999).

Ground water beneath Area 2 is in a series of aquifers composed of permeable sand, gravel, or fill materials separated by finer grained silt or clay layers. Contamination at Area 2 is known to occur only in the approximately 30 -ft thick unconfined aquifer beneath the site, and only that aquifer is described in this report; see Kahle (1998) and Jones (1999) for information about deeper sediments.

The unconfined aquifer consists of five defined waterbearing units, many present over limited areas, overlying a regionally extensive and thick confining unit consisting of clay and silt (URS Consultants, Inc., 1993). The uppermost water-bearing unit consists of about $10 \mathrm{ft}$ of artificial fill. Most fill is unsaturated and has variable lithology and permeability. A discontinuous unit consisting of as much as a few feet of organic-rich silt, clay, and sand lies beneath the fill. These marsh and tide flats deposits are mostly fine-grained, but generally are not compacted and are somewhat permeable. A discontinuous unit consisting of as much as $15 \mathrm{ft}$ of sand and sandy gravel lies beneath the marsh and tide flats deposits. These advance glacial outwash deposits are highly permeable. A continuous unit consisting of as much as $25 \mathrm{ft}$ of silt, fine sand, and clay lies beneath the outwash deposits. These non-glacial deposits have relatively low permeability, but not low enough to be considered a confining layer by previous site investigators. The lowest part of the uppermost aquifer is a continuous unit consisting of 2-7 ft of clean to silty sand with local gravel. These non-glacial deposits have moderate permeability.

\section{Surface-Water and Ground-Water Flow}

Small perennial creeks north and south of the former Building 957 drum storage area flow from the southwest to the northeast towards the shallow lagoon. Ground water flows from the southwest towards the northeast beneath the site, and likely discharges to the northern creek at some distance downgradient from storage area (fig. 2). Water levels at the site are not tidally influenced. The horizontal hydraulic gradient beneath the site is about $0.05 \mathrm{ft} / \mathrm{ft}$ (URS Consultants, Inc., 1993), and the estimated hydraulic conductivities for the uppermost aquifer range from 0.14 to $11 \mathrm{ft} / \mathrm{d}$, with a geometric mean of $1.2 \mathrm{ft} / \mathrm{d}$ (URS Consultants, Inc., 1993). The slug tests used to estimate hydraulic conductivities did not indicate any depth specific or consistent spatial trends. Assuming an effective porosity of 0.25 for the aquifer, the estimated linear ground-water flow velocity ranges from 0.03 to $2.2 \mathrm{ft} / \mathrm{d}$ with an assumed geometric mean of $0.24 \mathrm{ft} / \mathrm{d}$.

\section{Acknowledgments}

The author thanks Douglas Thelin of the Naval Facilities Engineering Command, Engineering Field Activity, Northwest for his guidance and for securing funding for the continued monitoring. Gene Ellis of NUWCD Keyport provided logistic support for field activities. Bernie Wong of CH2M HILL Constructors, Inc., in Bellevue, Wash. provided additional chloroethene data.

\section{Sample Collection and Analysis}

Water-level measurements and sample collection, processing, and field analyses were made in accordance with applicable USGS procedures (U.S. Geological Survey, 1997 to 2004) except samples were collected using a peristaltic pump. The geochemical measurements and concentrations determined for water samples from wells included dissolved hydrogen $\left(\mathrm{H}_{2}\right)$, dissolved oxygen (DO), filtered organic carbon, filtered nitrate plus nitrite, filtered manganese, filtered iron (II), filtered sulfate, unfiltered sulfide, dissolved methane, dissolved carbon dioxide, $\mathrm{pH}$, specific conductance, and filtered chloride. Concentrations of 64 volatile organic compounds (VOCs), including the chloroethenes of interest, were analyzed by the USGS for water samples from five of the wells, and chloroethene concentrations were analyzed by the Navy for samples from three other wells. Monitoring wells sampled were different depths and diameters (table 1), but all were constructed with PVC casings and screens with sand filter packs. 
Table 1. Construction data and water-level measurements for selected monitoring wells at former Building 957 drum storage area, Area 2 , Naval Undersea Warfare Center, Division Keyport, Washington, June 23, 2003.

[Well No.: MW, monitoring well. USGS site No.: Unique number for each site based on latitude and longitude of the site. First six digits are latitude, next seven digits are longitude, and final two digits are a sequence number to uniquely identify each site. Altitudes of water levels and measuring points: Feet above or below (-) NAVD 88. Depth of well and screened interval: Feet below land surface. Measuring point: Water levels in wells usually are reported as depths below land surface, although the measuring point can be any convenient fixed place near the top of well. For these wells and piezometers, measuring points are marked points on the tops of well casings and vary from being near the land surface to a few feet above land surface. Altitude of the measuring point commonly is recorded so static water levels also can be reported as altitudes. Abbreviations: ft, foot; in., inch; -, no data]

\begin{tabular}{|c|c|c|c|c|c|c|c|c|}
\hline Well No. & USGS site No. & Time & $\begin{array}{l}\text { Water level } \\
\text { altitude } \\
\text { (ft) }\end{array}$ & $\begin{array}{c}\text { Water level } \\
\text { (ft below } \\
\text { measuring } \\
\text { point) }\end{array}$ & $\begin{array}{c}\text { Altitude of } \\
\text { measuring } \\
\text { point } \\
\text { (ft) }\end{array}$ & $\begin{array}{c}\text { Depth of well } \\
(\mathbf{f t})\end{array}$ & $\begin{array}{l}\text { Casing } \\
\text { diameter } \\
\text { (in.) }\end{array}$ & $\begin{array}{c}\text { Screened } \\
\text { interval } \\
\text { (ft) }\end{array}$ \\
\hline $2 \mathrm{MW}-1$ & 474134122372601 & 1145 & 18.71 & 4.69 & 23.40 & 19.0 & 2 & $3-18$ \\
\hline $2 \mathrm{MW}-2$ & 474136122372501 & 1335 & 14.29 & 5.81 & 20.10 & 21.0 & 2 & $5-20$ \\
\hline $2 \mathrm{MW}-3$ & 474136122372301 & 1415 & 12.32 & 6.78 & 19.10 & 20.0 & 2 & $4.5-19.5$ \\
\hline $2 \mathrm{MW}-5$ & - & - & - & - & - & - & - & - \\
\hline 2MW-6 & 474136122372401 & 1530 & 11.17 & 7.15 & 18.32 & 19.0 & 2 & $7-14$ \\
\hline MW2-5 & 474136122372601 & 1115 & 16.43 & 4.73 & 21.16 & 16.0 & 4 & $5-15$ \\
\hline MW2-6 & - & - & - & - & - & 37.0 & 4 & $26-36$ \\
\hline MW2-7 & - & - & - & - & - & 32.0 & 4 & $21-31$ \\
\hline
\end{tabular}

After measuring depth to water, all samples were collected with a peristaltic pump and single-use polyurethane tubing. A stainless-steel weight was attached to the bottom of the tubing to accurately collect the sample from the midscreen elevation in each well. Samples were collected after approximately three casing-volumes of water were purged from the wells and after allowing $\mathrm{pH}$, specific conductance, and DO to stabilize (within 0.1 units, 5 percent, and $0.3 \mathrm{mg} / \mathrm{L}$, respectively). The three analytes were measured in a flow-through chamber using temperature-compensated sensors from a YSI ${ }^{\mathrm{TM}}$ data sonde. The specific conductance sensor was checked daily with standard reference solutions; the $\mathrm{pH}$ sensor was calibrated daily with two $\mathrm{pH}$ standards; and the dissolved-oxygen sensor was calibrated daily with watersaturated air and occasionally verified with zero dissolvedoxygen solution. Dissolved-oxygen analyses were confirmed for most water samples using 0 to $1 \mathrm{mg} / \mathrm{L}$ CHEMets Rhodazine-DTM colorimetric ampoules (manufactured by CHEMetrics, Inc., Calverton, Va.). The ampoules were filled directly from the sampling tube after well purging was complete.

Iron (II) concentrations were measured in the field in a sample filtered through a $0.45-\mu \mathrm{m}$ membrane filter using a colorimetric 1,10 phenanthroline indicator method and a Hach Model 2010 spectrophotometer according to Hach analytical method number 8146 (Hach Company, 1998). Sulfide concentrations were measured in the field using a colorimetric methylene-blue indicator method using the same spectrophotometer according to analytical method number 8131 (Hach Company, 1998). Information about the methodologies used to determine iron and sulfide concentrations is described at http://www.hach.com. Dissolved carbon dioxide $\left(\mathrm{CO}_{2}\right)$ concentrations were measured in the field using Titret ${ }^{\circledR}$-Sodium hydroxide tirtrant with a $\mathrm{pH}$ indicator (manufactured by CHEMetrics, Inc., Calverton, Va.).

Dissolved $\mathrm{H}_{2}$ in ground water was sampled using the bubble-strip method of Chapelle and others (1997). Concentrations were measured in the field using a gas chromatograph equipped with a reduction gas detector. Initial gas samples from each well were collected and analyzed after at least 20 minutes of stripping; subsequent samples were collected and analyzed at about 5-minute intervals until consecutive $\mathrm{H}_{2}$ concentrations stabilized to within 10 percent, a process that often required 1 hour or more.

Samples collected to determine nitrate, manganese, sulfate, and chloride concentrations were filtered through a $0.45-\mu \mathrm{m}$ membrane filter into polyethylene bottles, chilled, and sent to the USGS National Water Quality Laboratory (NWQL) in Lakewood, Colo. The manganese sample was acidified in the field with nitric acid to a pH less than 2, and then analyzed at NWQL by inductively coupled plasma as described by Fishman (1993). Chloride and sulfate concentrations were analyzed using ion chromatography as described by Fishman and Friedman (1989). Nitrate plus 
nitrite concentrations (reported as nitrite plus nitrate as $\mathrm{N}$ ) were analyzed colorimetrically by cadmium reduction and diazotization as described by Fishman (1993). Results for the nitrate plus nitrite analyses are referred to simply as nitrate in this report because of the expected small nitrite contribution to the total concentration.

Samples for dissolved organic carbon analysis were filtered through a $0.45-\mu \mathrm{m}$ filter, collected in amber glass bottles, acidified in the field with sulfuric acid to a $\mathrm{pH}$ less than 2 , chilled to less than $4^{\circ} \mathrm{C}$, and shipped to the USGS laboratory in Ocala, Fla., for analysis. Organic carbon concentrations were measured using high temperature combustion according to Standard Method 5310B as described by Franson (1992).

Samples for dissolved methane analysis were collected in 150-mL glass bottles, sealed with rubber stoppers, chilled to less than $4^{\circ} \mathrm{C}$, and analyzed at the USGS Field Services Unit in Tacoma, Wash. Samples were analyzed using a gas chromatograph with a flame-ionization detector as described by Kampbell and others (1989). Samples for VOC analysis were collected in pre-acidified 40-mL glass vials, placed on ice, and shipped to the Severn Trent Laboratories in Denver, Colo., for analysis using purge and trap capillary-column gas chromatography/mass spectrometry (Method 8260B, U.S. Environmental Protection Agency, 1996).

\section{Evidence for Chloroethene Biodegradation in Ground Water}

\section{Geochemical Data and Predominant Redox Conditions}

June 2003 geochemical data and inferred predominant reduction-oxidation (redox) conditions are shown in table 2. The predominant redox conditions were inferred by considering dissolved oxygen and dissolved $\mathrm{H}_{2}$ concentrations combined with other geochemical concentrations. Dissolvedoxygen concentrations greater than $1 \mathrm{mg} / \mathrm{L}$ generally indicate aerobic conditions and concentrations less than $1 \mathrm{mg} / \mathrm{L}$ indicate one of the anaerobic conditions. Exceptions are possible when water levels in low-yield monitoring wells are drawn down by pumping while being sampled, or when long well screens intersect aerobic ground water near the water table and anaerobic ground water at greater depths. Chapelle and others (1995) developed a method to determine the specific redox condition of anaerobic ground water based on dissolved $\mathrm{H}_{2}$ concentrations, where less than 0.05 nanomolar $(\mathrm{nM})$ indicates manganese or nitrate reduction, $0.1-0.8 \mathrm{nM}$ indicates iron reduction, 1-5 $\mathrm{nM}$ indicates sulfate reduction, and greater than $5 \mathrm{nM}$ indicates methanogenesis. Exceptions are common in contaminant plumes because of complicating effects from different absolute concentrations of dissolved redox species, from different iron-oxide minerals that serve as electron acceptors, from different ground-water temperatures, and from overlapping and not exclusive redox conditions (Hoehler and others, 1998; Jakobsen and others, 1998; Christensen and others, 2000). Therefore, all geochemical data and best professional judgment were used to infer the predominant redox conditions listed in table 2. For instance, at well MW2-8, the $1.5 \mathrm{mg} / \mathrm{L}$ of dissolved oxygen measured was not likely indicative of predominantly aerobic conditions in the aquifer. The dissolved-oxygen concentration at MW2-8 decreased steadily to less than $1 \mathrm{mg} / \mathrm{L}$ during the first 30 minutes of low-flow purging, but the concentration then increased steadily to $1.5 \mathrm{mg} / \mathrm{L}$ as purging continued and the well nearly went dry. Ground water entering the well and trickling down the screen to the pump intake likely added dissolved oxygen to the sample. The manganese concentration of $3.0 \mathrm{mg} / \mathrm{L}$ at MW2-8 is not consistent with aerobic conditions in the aquifer, and manganese concentrations are not affected by drawdown during sampling.

At former Building 957 drum storage area, aerobic redox conditions were inferred only at well $2 \mathrm{MW}-1$ near the southwest corner of the site. Dissolved-oxygen concentration at well $2 \mathrm{MW}-1$ was $1.0 \mathrm{mg} / \mathrm{L}$, nitrate concentration was $0.62 \mathrm{mg} / \mathrm{L}$, and only trace concentrations of iron (II) and manganese were detected. These data clearly indicate that the 15-ft long screen intersects aerobic ground water, but also may intersect anaerobic water at depth. The lowest concentrations of dissolved organic carbon $(3.7 \mathrm{mg} / \mathrm{L})$ and carbon dioxide $(35 \mathrm{mg} / \mathrm{L})$ were measured in a water sample collected from well $2 \mathrm{MW}-1$, which is consistent with relatively low microbial activity and limited dissolved-oxygen consumption.

The anaerobic redox conditions and geochemical concentrations detected in seven of eight wells sampled varied considerably across the relatively small site. Although all dissolved $\mathrm{H}_{2}$ concentrations indicated iron reduction as the predominant redox condition, other geochemical concentrations indicated additional redox conditions were present in the shallow aquifer at the site. Manganese concentrations at wells 2MW-3, 2MW-4, and MW2-8 nearly equaled or exceeded iron (II) concentrations, indicating substantial manganese reduction at or near those wells. Relatively high sulfide and methane concentrations and relatively low sulfate concentration at well $2 \mathrm{MW}-2$ indicated sulfate reduction and methanogenesis at or near that well. The lack of sulfide and sulfate with corresponding high methane concentration at $2 \mathrm{MW}-6$ indicated methanogenesis likely was the predominant redox processes at that well. 
Table 2. Predominant reduction-oxidation (redox) conditions and ground-water geochemical data collected at former Building 957 drum storage area, Area 2, Naval Undersea Warfare Center, Division Keyport, Washington, June 23, 2003.

[Well No.: MW, monitoring well. Predominant redox condition: A, aerobic; Fe, iron reducing; M, methanogenic; Mn, manganese reducing; S, sulfate reducing. Abbreviations: nM, nanomolar; mg/L, milligram per liter; N, nitrogen; $\mu \mathrm{S} / \mathrm{cm}$, microsiemen per centimeter at $25^{\circ}$ Celsius. -, not analyzed; $<$, actual value is less than value shown]

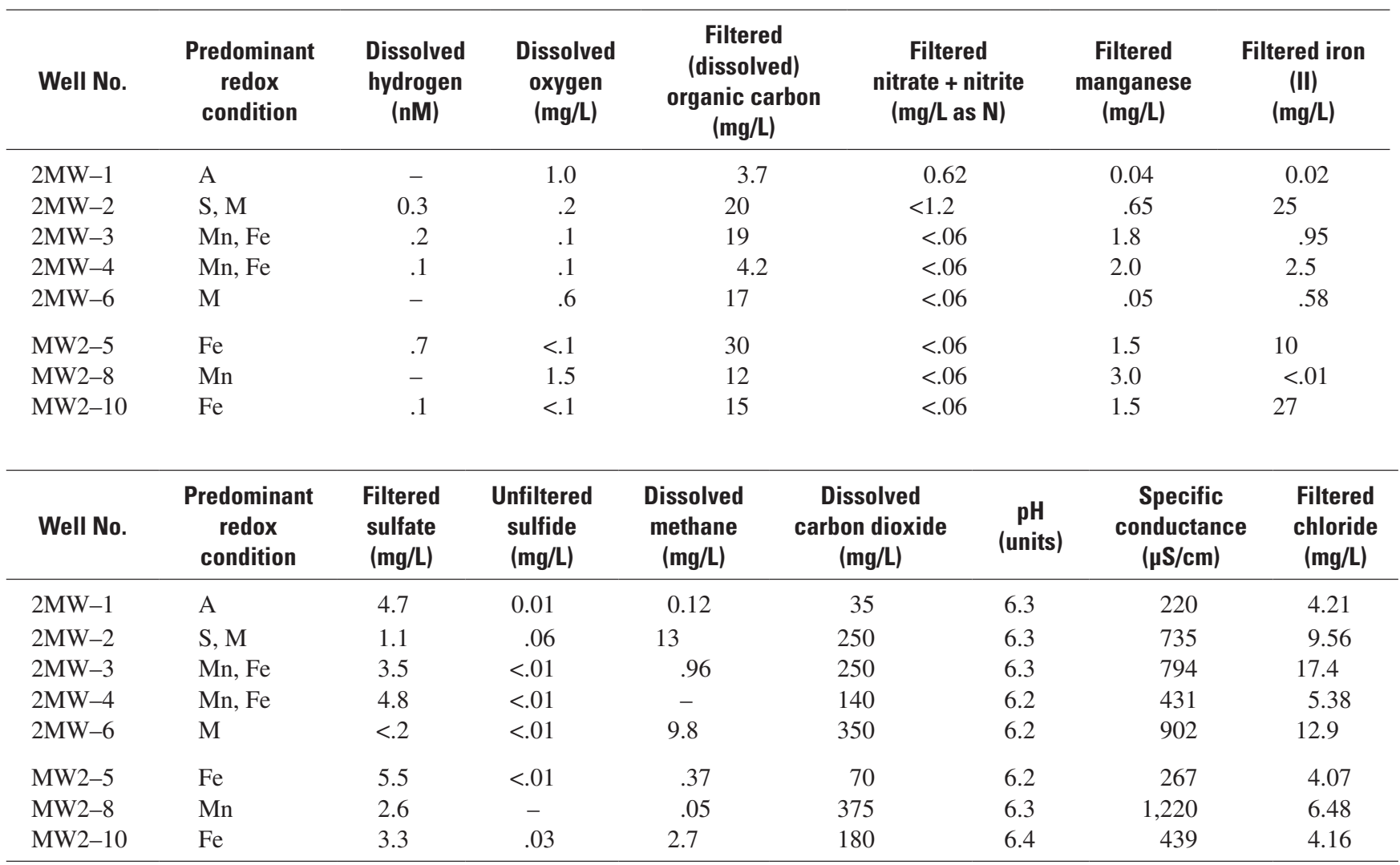

A predominant redox condition was inferred for each sample, although the geochemical data from most water samples did not indicate that the assigned redox condition was exclusive. Most wells sampled at the study site are screened across at least two of the five defined water-bearing units beneath Area 2, and those units vary substantially in their organic carbon contents (URS Consultants, Inc., 1993). Organic carbon is a primary control of redox conditions, so redox conditions likely changed over short vertical distances in the heterogeneous aquifer at the site, and sampling drew water to the well from zones with different redox conditions.

Historical dissolved iron and manganese concentrations measured in selected wells during 1991-92 (URS Consultants, Inc., 1993) were similar to those measured in 2003 with two exceptions. Neither iron nor manganese was detected in water samples from well 2MW-2 during 1992 (with detection limits of 0.62 and $0.06 \mathrm{mg} / \mathrm{L}$, respectively), whereas the 2003 iron (II) and manganese concentrations were substantially greater
(25 and $0.65 \mathrm{mg} / \mathrm{L}$, respectively). At well MW2-5, the 1992 iron and manganese concentrations in samples were $<0.62$ and $0.32 \mathrm{mg} / \mathrm{L}$, respectively, whereas the 2003 concentrations were substantially greater (10 and $1.5 \mathrm{mg} / \mathrm{L}$, respectively). The substantial increases in dissolved-metals concentrations may indicate that redox conditions changed from aerobic to anaerobic sometime between 1992 and 2003.

The 2003 dissolved organic carbon concentrations in water samples from the two most upgradient wells (2MW-1 and $2 \mathrm{MW}-4$ ) ranged from 3.7 to $4.2 \mathrm{mg} / \mathrm{L}$, whereas the concentration in samples from the other six wells farther downgradient ranged from 12 to $30 \mathrm{mg} / \mathrm{L}$. The downgradient concentrations are relatively high, and can be reasonably expected to help maintain anaerobic conditions in shallow ground water in the foreseeable future. Historical carbon data are not available for evaluating changes and persistence of anaerobic conditions over time. 


\section{Possible Biodegradation Mechanisms for Chloroethenes}

The many possible biodegradation mechanisms for chloroethenes can be broadly categorized in two groupsreductive dechlorination and microbial oxidation. Reductive dechlorination is a process where electrons are transferred from relatively simple organic compounds (electron donors) to chloroethenes (electron acceptors), replacing a chlorine atom to create daughter products with one less chlorine atom. Microbial oxidation is a process where chloroethenes serve as the electron donor (are oxidized) directly to chlorine and carbon dioxide through various pathways catalyzed by micro-organisms. Details of those mechanisms have been determined by multiple researchers over the last few decades and are not repeated in this report-refer to Bradley (2003) for a current and thorough review on the history and ecology of chloroethene biodegradation. Occurrence and potential efficiency of specific mechanisms for chloroethene biodegradation at a given contamination site are particularly sensitive to redox conditions of the ground water contaminant plume (table 3). Generally, reductive dechlorination mechanisms are most favorable under strongly anaerobic redox conditions (such as methanogenesis and sulfate reduction), and are most efficient for biodegradation of the more highly chlorinated compounds tetrachloroethene (PCE) and TCE. Reductive dechlorination mechanisms are common in anaerobic ground water and are thought to be the primary cause for biodegradation of the parent compounds PCE and TCE to form the daughter products DCE and VC. Conversely, microbial oxidation mechanisms are most favorable under aerobic or mildly anaerobic redox conditions (manganese and iron reduction), and are most efficient for biodegradation of the less chlorinated compounds cis-DCE and VC. Widespread occurrence of microbial oxidation mechanisms is not as well documented as that of reductive dechlorination, in large part because the oxidation daughter products carbon dioxide and chloride are not uniquely diagnostic to chloroethene biodegradation. Regardless, the potential for microbial oxidation mechanisms under aerobic conditions can be substantial where an anaerobic contaminant plume encounters aerobic water (such as at a discharge point to surface water), and the potential for microbial oxidation of VC and DCE under anaerobic conditions can be substantial in contaminant plumes where redox conditions are only mildly reducing.

\section{Chloroethene Data}

Chloroethene concentrations from 1991 through 2004 are shown in table 4. August 2003 data were collected and analyzed by the USGS; all other data were collected and analyzed by the Navy and retrieved in 2004 by the USGS from the Navy's Technical Data Management System. In addition to the eight wells sampled for geochemicals by the USGS during 2003, data are shown for two wells screened near the bottom of the upper aquifer at the site (MW2-6 and MW2-7) to illustrate that contaminants have not been detected at depth, and one shallower well (2MW-5) to illustrate the decrease in upgradient TCE concentrations measured between 1995 and 1998.

During 2003, only TCE was detected near the upgradient margin of former Building 957 drum storage area (well 2MW-1), and only cis-DCE and VC were detected near the downgradient margin of the site (wells 2MW-3 and 2MW-6) (fig. 3). Total BTEX was detected only at well $2 \mathrm{MW}-3$ at a concentration of $0.21 \mu \mathrm{g} / \mathrm{L}$ (data not shown).

Table 3. Potential relative efficiency of chloroethene biodegradation through microbial reductive dechlorination or microbial oxidation as a function of in situ redox conditions.

[Data from Bradley (2003). Contaminant: PCE, tetrachloroehthene; TCE, trichloroethene; cis-DCE, cis-1,2-dichloroethene; VC, vinyl chloride. Biodegradation mechanism: MO, microbial oxidation; RD, reductive decholrination. Predominant redox condition: -, indicates no evidence for this mechanism under this redox condition]

\begin{tabular}{ccccccc}
\hline \multirow{2}{*}{ Contaminant } & $\begin{array}{c}\text { Biodegradation } \\
\text { mechanism }\end{array}$ & Aerobic & $\begin{array}{c}\text { Manganese } \\
\text { reduction }\end{array}$ & Iron reduction & Sulfate reduction & Methanogenesis \\
\cline { 3 - 7 } PCE & $\mathrm{RD}$ & - & Good & Good & Excellent & Excellent \\
& $\mathrm{MO}$ & Fair & - & - & - & - \\
$\mathrm{TCE}$ & $\mathrm{RD}$ & - & Fair & Good & Good & Excellent \\
& $\mathrm{MO}$ & Good & - & - & - & - \\
\multirow{2}{*}{ cis-DCE } & $\mathrm{RD}$ & Poor & Poor & Poor & Fair & Good \\
& $\mathrm{MO}$ & Excellent & Good & Poor & Poor & Poor \\
$\mathrm{VC}$ & $\mathrm{RD}$ & Poor & Poor & Poor & Fair & Fair \\
& $\mathrm{MO}$ & Excellent & Excellent & Excellent & Good & Good $^{2}$ \\
\hline
\end{tabular}

\footnotetext{
${ }^{1}$ Aerobic cometabolism only — considered to be a transient mechanism.

${ }^{2}$ Associated with humic-acids reduction rather than methanogenic activity.
} 
Table 4. Chloroethene concentrations in ground water at former Building 957 drum storage area, Area 2, Naval Undersea Warfare Center, Division Keyport, Washington, 1991 to 2004.

[All concentrations are in micrograms per liter. All data except those from August 2003 were collected by the U.S. Navy. Positive detections are bold. Well No.: MW, monitoring well. Concentrations: PCE, tetrachloroethene; TCE, trichloroethene; cis-DCE, cis-1,2-dichloroethene; trans-DCE, trans-1,2-dichloroethene; 1,2-DCE, total 1,2-dichloroethene; VC, vinyl chloride. Abbreviations: na; not applicable. Symbols: $<$, actual value is less than value shown; -, not analyzed]

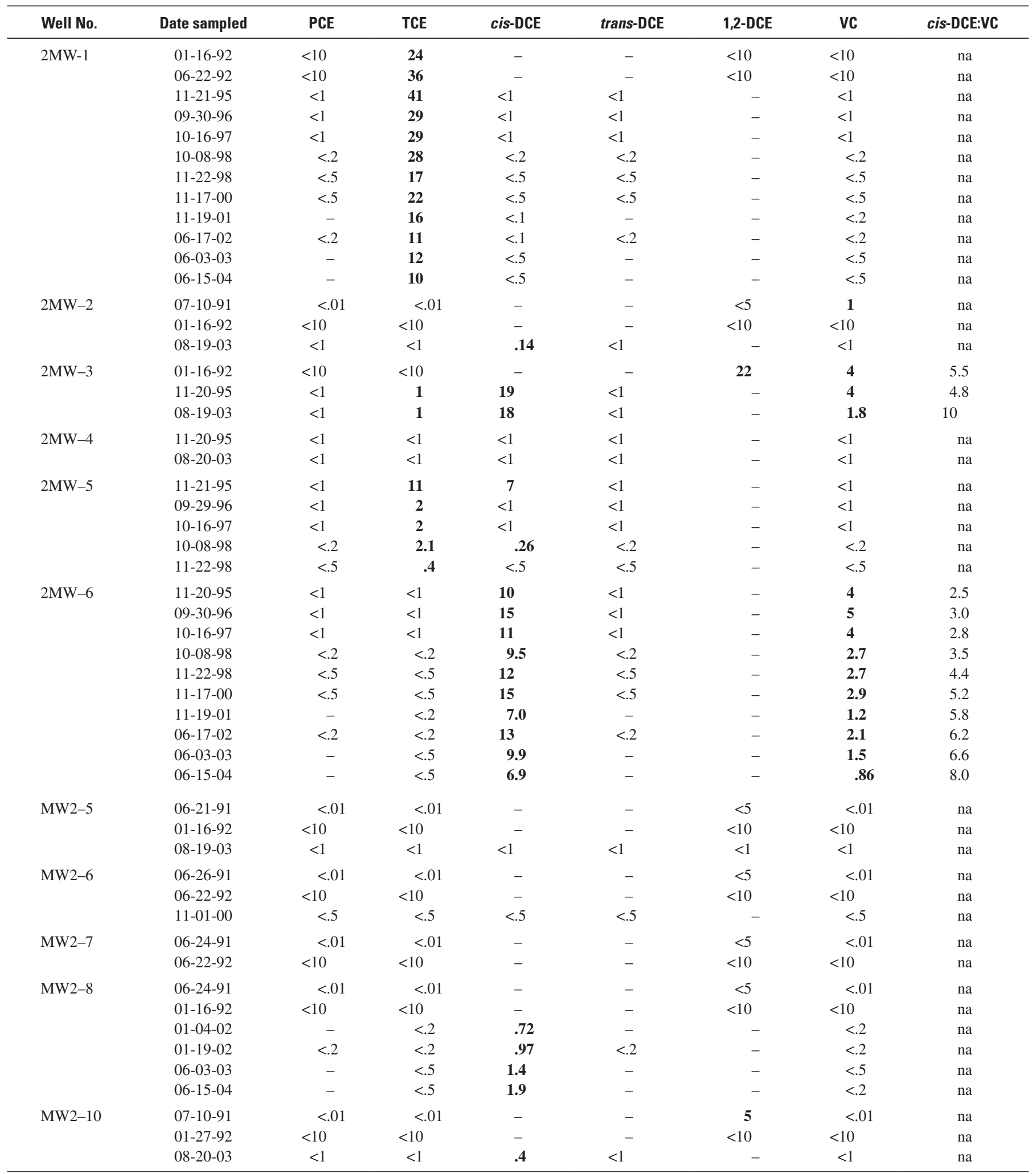




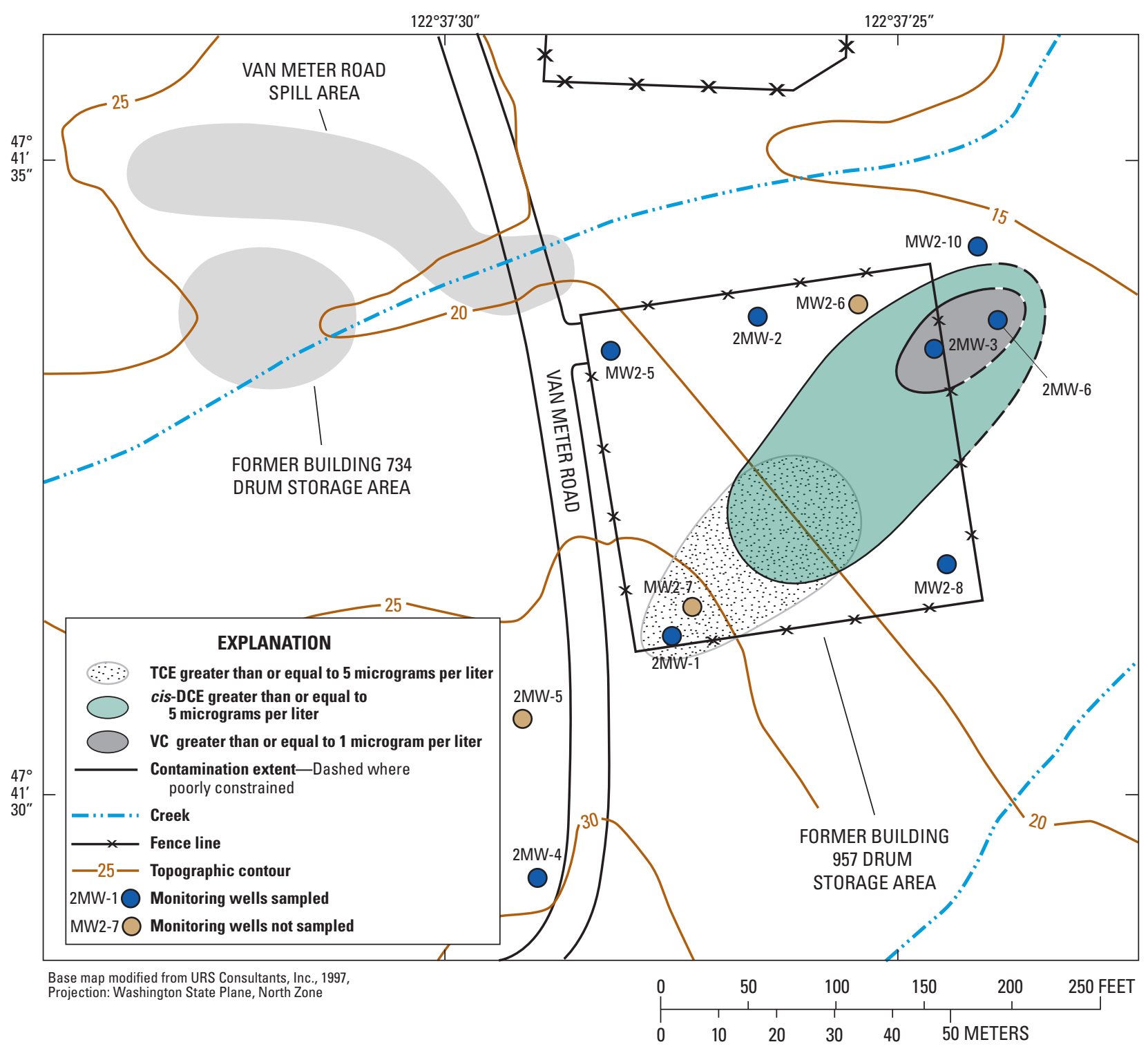

Figure 3. Concentrations of trichloroethene (TCE), cis-dichloroethene (cis-DCE), and vinyl chloride (VC) in ground water at former Building 957 drum storage area, Area 2, Naval Undersea Warfare Center, Division Keyport, Washington, June and August 2003.

\section{Evaluation of Evidence for Chloroethene Biodegradation}

The U.S. Environmental Protection Agency protocol (Wiedemeier and others, 1998) for evaluation of natural attenuation of chlorinated solvents in ground water recommends multiple lines of evidence. Because biodegradation is considered a critical component of natural attenuation, many of those lines of evidence are appropriate, including: (1) demonstration of existence of redox conditions conducive to known mechanisms of chloroethene biodegradation; (2) demonstration of production of daughter products indicative of chloroethene biodegradation; and (3) demonstration of a distinct trend toward decreasing chloroethene concentrations. Geochemical and chloroethene data collected for this investigation were evaluated according to those three lines of evidence.

The potential for specific chloroethene biodegradation mechanisms at the former Building 957 drum storage area was determined by comparing ground-water redox conditions to the data shown in table 4, and the likelihood that the mechanisms are actually occurring were inferred from 
measured contaminant concentrations. The evaluation focused on the presumed contaminant flow path at the site extending from well $2 \mathrm{MW}-1$ downgradient to wells $2 \mathrm{MW}-3$ and 2MW-6. That flow path is consistent with the June 2003 water levels measured at the site (fig. 2). The three wells of interest are the only wells where recent contaminant concentrations exceeded the remediation goals established for the site. Those remediation goals are $5 \mu \mathrm{g} / \mathrm{L}$ for TCE, $70 \mu \mathrm{g} / \mathrm{L}$ for cis-DCE, and $1 \mu \mathrm{g} / \mathrm{L}$ for VC (URS Consultants, Inc., 1994).

At the upgradient (southwest) corner of the former Building 957 drum storage area (well 2MW-1), aerobic redox conditions were inferred. Reductive dechlorination of TCE does not occur under aerobic conditions, which is consistent with the detection of TCE at 2MW-1 and the corresponding lack of cis-DCE and VC daughter products. TCE concentrations at well 2MW-1 generally decreased between 1992 and 2004 (table 4, but the lack of daughter products at the well indicates that the trend likely is due to non-destructive attenuation mechanisms such as dilution or dispersion.

At the two most contaminated downgradient wells at the site (2MW-3 and 2MW-6), the inferred redox conditions were manganese/iron reducing and methanogenic, respectively. The potential for reductive dechlorination of TCE is good to excellent under such conditions, which is consistent with measured TCE concentrations of only $1 \mu \mathrm{g} / \mathrm{L}$ at the manganese/iron reducing well, and $<0.5 \mu \mathrm{g} / \mathrm{L}$ at the methanogenic well. Concentrations of daughter products cis-DCE and VC were substantially greater than the TCE concentrations at the downgradient wells. TCE concentrations at wells 2MW-3 and 2MW-6 always have been low (table 4) and substantially less than the $5 \mu \mathrm{g} / \mathrm{L}$ remediation goal for the site.

The potential for reductive dechlorination of cis-DCE is poor under manganese/iron reducing conditions and good under methanogenic conditions, consistent with the higher cis-DCE concentration of $18 \mu \mathrm{g} / \mathrm{L}$ at the manganese/iron reducing well (2MW-3) compared to the lower $9.9 \mu \mathrm{g} / \mathrm{L}$ concentration at the methanogenic well (2MW-6). The cis-DCE concentrations at wells 2MW-3 and 2MW-6 always have been less than $20 \mu \mathrm{g} / \mathrm{L}$ with no strong increases or decreases during the period of record (table 4). Those concentrations are substantially less than $70 \mu \mathrm{g} / \mathrm{L}$ remediation goal for the site. However, cis-DCE concentrations less than the remediation goal are still a concern because of reductive dechlorination into $\mathrm{VC}$, which has a remediation goal of only $1 \mu \mathrm{g} / \mathrm{L}$ at the site.

The potential for microbial oxidation of $\mathrm{VC}$ is excellent to good under manganese/iron reducing and methanogenic redox conditions, but the potential for reductive dechlorination of VC is only fair. In contrast to cis-DCE concentrations, VC concentrations at wells $2 \mathrm{MW}-3$ and $2 \mathrm{MW}-6$ have decreased over 9 to 14 years, and an increase was measured in the ratio of cis-DCE to VC concentrations (table 4). Those data indicate that $\mathrm{VC}$ is less persistent than cis-DCE in the downgradient wells, which is strong evidence for relatively efficient microbial oxidation of VC. The potential for microbial oxidation of cis-DCE is good under manganese reducing conditions (indicated at well $2 \mathrm{MW}-3$ by the relatively high manganese concentration of $1.8 \mathrm{mg} / \mathrm{L}$ ), but overall it appears that the biodegradation rate for cis-DCE from both reductive dechlorination and microbial oxidation is less than the biodegradation rate for VC. The daughter products from microbial oxidation of $\mathrm{VC}$ are carbon dioxide and chloride, and the concentrations of those analytes in well 2MW-3 and 2MW-6 were substantially higher than those detected upgradient at well 2MW-1 (table 2). Carbon dioxide and chloride concentrations were significantly higher than concentrations resulting from biodegradation of a few micrograms per liter of chloroethenes; therefore, the carbon dioxide and chloride data alone are not direct evidence for microbial oxidation. The increase in the cis-DCE to $\mathrm{VC}$ ratio over time, however, is strong evidence for microbial oxidation of VC because non-destructive attenuation mechanisms such as dispersion or dilution likely would not affect the $c i s$-DCE to $\mathrm{VC}$ ratio.

\section{Summary and Conclusions}

Geochemical and chloroethene data indicated that much of the trichloroethene (TCE) and vinyl chloride (VC), and some of the cis-1,2-dichloroethene (cis-DCE) biodegraded in ground water as it flowed beneath and slightly beyond the former Building 957 drum storage area at the Naval Undersea Warfare Center, Division Keyport, Washington. No apparent TCE biodegradation through any mechanism was indicated at the upgradient margin of the former drum storage area where aerobic ground water was indicated. Substantial reductive dechlorination of TCE and cis-DCE was indicated in the downgradient anaerobic ground water. Reductive dechlorination was definitively indicated by the presence of the daughter products cis-DCE and VC in downgradient wells. Ground-water redox conditions were favorable for biodegradation through microbial oxidation of VC (and cis-DCE to a lesser extent) in downgradient wells, and measured increases in the ratio of cis-DCE to VC over time at those wells was strong evidence for microbial oxidation of VC. All chloroethene concentrations detected in ground water at the former Building 957 drum storage area were less than 20 micrograms per liter. In the three wells where the 2003 TCE or VC concentrations exceeded remediation goals, the concentrations have consistently decreased over time. 


\section{References Cited}

Blunt, D.J., Easterbrook, D.J., and Rutter, N.W., 1987, Chronology of Pleistocene sediments in the Puget Lowland, Washington: Washington Division of Geology and Earth Resources, Bulletin 77, p. 321-353.

Bradley, P.M., 2003, History and ecology of chloroethene biodegradation: A review: Bioremediation Journal, v. 7, no. 2, p. 81-109.

CH2M HILL Constructors, Inc., 2003, Spring 2003 long-term monitoring data report, Van Meter Road spill/drum storage area, Area 2, Operable Unit 2, Naval Undersea Warfare Center Division Keyport, Washington: Prepared under Contract Task Order 0062 for Engineering Field Activity Northwest, Naval Facilities Engineering Command, Poulsbo, Wash.

Chapelle, F.H., McMahon, P.B., Dubrovsky, N.M., Fujii, R.F., Oaksford, E.T., and Vroblesky, D.A., 1995, Hydrogen $\left(\mathrm{H}_{2}\right)$ concentrations as an indicator of terminal electron accepting processes (TEAP's) in diverse ground-water systems: Water Resources Research, v. 32, p. 359-371.

Chapelle, F.H., Vroblesky, D.A., Woodward, J.C., and Lovely, D.R., 1997, Practical considerations for measuring hydrogen concentrations in groundwater: Environmental Science and Technology, v. 31, no. 10, p. 2873-2877.

Christensen, T.H., Bjerg, P.L., Banwart, S.A., Jakobsen, R., Heron, G., and Albrechtsen, H.J., 2000, Characterization of redox conditions in groundwater contaminant plumes: Journal of Contaminant Hydrology, v. 45, p. 165-241.

Fishman, M.J., ed., 1993, Methods of analysis by the U.S. Geological Survey National Water Quality LaboratoryDetermination of inorganic and organic constituents in water and fluvial sediments: U.S. Geological Survey Open-File Report 93-125, 217 p.

Fishman, M.J., and Friedman, L.C., 1989, Methods for determination of inorganic substances in water and fluvial sediments: U.S. Geological Survey Techniques of WaterResources Investigations, book 5, chap. A1, 545 p.

Franson, M.H., ed., 1992, Standard methods for the examination of water and wastewater (18th ed.): American Public Health Association, American Water Works Association, and Water Environment Federation, Washington, D.C.

Hach Company, 1998, DR/2010 Spectrophotometer procedures manual: Hach Company, Loveland, Colo.

Hoehler, T.M., Alperin, M.J., Albert, D.B., and Martens, C.S., 1998, Thermodynamic controls on $\mathrm{H}_{2}$ concentrations in anoxic sediments: Geochemica et Cosmochimica Acta, v. 62 , p. $1745-1746$.

Jakobsen, R., Albrechtsen, H.J., Rasmussen, M., Bay, H., Bjerg, P.L., and Christensen, T.H., 1998, $\mathrm{H}_{2}$ concentrations in a landfill leachate plume (Grinsted, Denmark): In situ energetics of terminal electron acceptor processes: Environmental Science and Technology, v. 32, no. 14, p. 2142-2148.
Jones, M.A., 1999, Geologic framework for the Puget Sound aquifer system, Washington and British Columbia: U.S. Geological Survey Professional Paper 1424-C, 31 p.

Kahle, S.C., 1998, Hydrogeology of Naval Submarine Base Bangor and vicinity, Kitsap County, Washington: U.S. Geological Survey Water-Resources Investigations Report 97-4060, 107 p.

Kampbell, D.H., Wilson, J.T., and Vandergrift, S.A., 1989, Dissolved oxygen and methane in water by a GC headspace equilibrium technique: International Journal of Environmental Analytical Chemistry, v. 36, p. 249-457.

U.S. Environmental Protection Agency, 1996: accessed December 2, 2005 at: http://www.epa.gov/epaoswer/ hazwaste/test/pdfs/8260b.pdf.

U.S. Geological Survey, 1997 to 2004, National field manual for the collection of water-quality data: U.S. Geological Survey Techniques of Water-Resources Investigations, book 9, chaps. A1-A9, 2 vols., variously paged. [Also available online at http://pubs.water.usgs.gov/twri9A.] Chapters originally were published from 1997-99; updates and revisions are ongoing and are summarized at: http:// water.usgs.gov/owq/FieldManual/mastererrata.html.

URS Consultants, Inc., 1993, Final remediation investigation report for Naval Undersea Warfare Center Division Keyport, Washington: Prepared under Contract No. N62474-89D-9295 for Engineering Field Activity Northwest, Naval Facilities Engineering Command, Poulsbo, Wash., 6 vols.

URS Consultants, Inc., 1994, Final record of decision for Operable Unit 2, Naval Undersea Warfare Center Division Keyport, Washington: Prepared under Contract Task Order 0010 for Engineering Field Activity Northwest, Naval Facilities Engineering Command, Poulsbo, Wash.

URS Consultants, Inc., 1997, Final summary data assessment report for Operable Unit 1 Naval Undersea Warfare Center Division Keyport, Washington: Prepared by URS Consultants, Seattle, Washington, for Engineering Field Activity, Northwest, Naval Facilities Engineering Command, Poulsbo, WA, 3 vols.

Washington State University, 1968, Washington climate for King, Kitsap, Mason, Pierce Counties: Washington State University Cooperative Extension Service, College of Agriculture, Pullman, Wash., E.M.2734, 66 p.

Wiedemeier, T.H., Swanson, M.A., Wilson, J.T., Wilson, B.H., Kampbell, D.K., Hass, P.E., Miller, R.N., Hansen, J.E., and Chapelle, F.H., 1998, Technical protocol for evaluating natural attenuation of chlorinated solvents in ground water: EPA/600/R-98/128, 78 p. 
Manuscript approved for publication, January 25, 2006

Prepared by the Enterprise Publishing Network

Publishing Service Center, Tacoma, Washington

Bill Gibbs

Debra Grillo

Sharon Wahlstrom

For more information concerning the research in this report, contact the Washington Water Science Center Director,

U.S. Geological Survey, 1201 Pacific Avenue - Suite 600

Tacoma, Washington 98402

http://wa.water.usgs.gov 

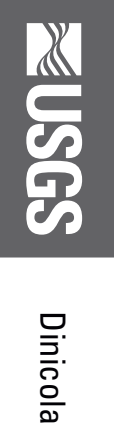

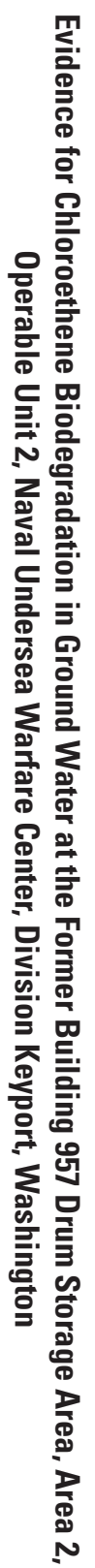

